\title{
Knowledge, perceptions and care needs of preoperative surgery for the realization of intestinal ostomy
}

\section{Conhecimentos, percepções e necessidades de cuidados em pré-operatório de cirurgia para a confecção de estomia intestinal}

\section{Conocimientos, percepciones y necesidades de cuidados preoperatorios de la cirugía para la realización del estoma intestinal}

Gabriela Xavier Morais,"*, Juliana Balbinot Reis Girondi², Lúcia Nazareth Amante", Luciara Fabiane Sebold ${ }^{2}$, Amanda de Souza Vieira ${ }^{2}$,Fernanda Ribeiro de Souza ${ }^{2}$

ORCID IDS

Morais GX iD https://orcid.org/0000-0003-2379-7908 Girondi JBR (iD https://orcid.org/0000-0003-0271-259X Amante LN (D) https://orcid.org/0000-0002-5440-2094 Sebold LF (Dhttps://orcid.org/0000-0002-5023-9058 Vieira AS (D) https://orcid.org/0000-0002-6176-4691 Souza FR (D) https://orcid.org/0000-0002-1999-926X
HOW TO CITE

Morais GX; Girondi JBR; Amante LN; Sebold LF; Vieira AS; Souza FR. Knowledge, perceptions and care needs of preoperative surgery for the realization of intestinal ostomy. ESTIMA, Braz. J. Enterostomal Ther., 17, 2019: e2519. https://doi.org/10.30886/estima.v17.721_IN

\begin{abstract}
Objective: To understand the perceptions and self-care needs of patients regarding intestinal stoma in the preoperative period. Method: Qualitative exploratory research performed in a surgical unit of a hospital in southern Brazil, with seven patients in the preoperative period of intestinal surgery. The data were collected through semi-structured interviews and submitted to thematic analysis of content. From the data analysis three thematic categories emerged: therapeutic itinerary and associated feelings; knowledge, perceptions and expectations regarding intestinal ostomy; and self-care needs of the patient with intestinal stoma. Results: The participants showed a lack of knowledge about intestinal stoma and evaluated this possibility as something negative, which would bring changes in lifestyle habits, with little information about care. Conclusion: It is evident the need to provide preoperative orientation for better acceptance and strengthening of the patient's self-care in the postoperative period, appointing the nurse as an essential professional in this process.
\end{abstract}

DESCRIPTORS: Ostomy; Self-care; Nursing care; Enterostomal therapy.

\section{RESUMO}

Objetivo: Conhecer as percepções e necessidades de autocuidado de pacientes sobre estomia intestinal no período pré-operatório. Método: Pesquisa qualitativa exploratório-descritiva realizada em unidade de internação cirúrgica de um hospital no sul do Brasil, com sete pacientes internados em pré-operatório de cirurgia intestinal. Os dados foram coletados mediante entrevistas semiestruturadas e submetidos à análise temática de conteúdo. Da análise dos dados emergiram três categorias temáticas: itinerário terapêutico e sentimentos associados; conhecimentos, percepções e expectativas sobre estomia intestinal; e necessidades de autocuidado do paciente com estomia intestinal. Resultados: Os participantes evidenciaram desconhecimento sobre estomia intestinal e avaliaram essa possibilidade como algo negativo, que acarretaria modificações de hábitos de vida, com poucas informações sobre

1.Secretaria Municipal de Saúde de Florianópolis - Atenção Primária à Saúde - Florianópolis/SC - Brazil.

2.Universidade Federal de Santa Catarina - Departamento de Enfermagem - Florianópolis/SC - BraZil.

*Correspondence author: gabrielaxmorais@gmail.com

Received: Apr. 09, 2019 | Accepted: Dec. 06, 2019 
os cuidados. Conclusão: Evidencia-se a necessidade do fornecimento de orientações no pré-operatório para melhor aceitação e fortalecimento do autocuidado do paciente no período pós-operatório apontando o enfermeiro como profissional essencial nesse processo.

\section{DESCRITORES: Estomia; Autocuidado; Cuidados de enfermagem; Estomaterapia.}

\section{RESUMEN}

Objetivo: Conocer la noción del autocuidado que tienen los pacientes sobre cirugías de ostomía intestinal en el preoperatoria. Método: Investigación cualitativa, siete pacientes hospitalizados en unidad quirúrgica de hospital universitario en el sur de Brasil, en el periodo preoperatorio de cirugías intestinales. Los datos fueron recolectados en encuestas semiestructuradas y sometidos al análisis temático de contenido. Análisis surgieron tres categorías: Itinerario terapéutico y sentimientos asociados; Conocimientos, percepciones y expectativas sobre los estomas intestinales; cuidados personales de pacientes con estomias intestinales. Resultados: Encuestados mostraron desconocimiento de ostomía intestinal con una impresión negativa, pues iban a modificar sus hábitos de vida y contaban con poca información sobre los cuidados y el autocuidado con estoma intestinal. Conclusión: Se evidenció la importancia de información en el preoperatorio para una mejor aceptación de este tipo de cirugías y fortalecer el autocuidado del paciente siendo el enfermero un profesional de vital importancia en este proceso.

DESCRIPTORES: Estomía; Autocuidado; Atención de enfermería; Estomaterapia.

\section{INTRODUCTION}

The perioperative period of a patient who will undergo a surgical procedure covers three distinct but interconnected phases. The preoperative phase comprises from the moment of decision making of the surgical intervention until the surgery itself. In this context of care, the nurse plays a key role in the implementation of safe nursing interventions suitable for the appropriate rehabilitation of the patient. In surgeries where there is a need to make an intestinal stoma, the person faces a new condition in which he/she undergoes several physiological, psychosocial, and psychospiritual changes. During this process, the individual suffers from decreased self-esteem and life perspectives, feelings of mourning, changes in personal, interpersonal, work, and social activities, needing to adapt to start this new phase of life ${ }^{1}$. In this sense, the nursing interventions that comprise the preoperative phase, such as clarification of doubts, explanations about changes in life habits, and necessary care are fundamental, since the person is more capable of understanding the information at this time. Such interventions reflect directly on the postoperative orientations, which will be focused on the difficulties of the patients and relatives, in order to contribute to the physical and psychological balance in the face of so many changes ${ }^{2-4}$.

The guidelines need to be enlightening as regards the definition of stomata, what they are for, how to handle them, and what the daily care routine will be like, always highlighting the positive aspects and the benefits $^{5}$. From this perspective, the nurse must know the care needs of these patients, considering that they permeate the biological aspect. A new rearrangement in the way of living and taking care of oneself is necessary, which configures new possibilities of self-expansion or retraction, for the world and society. The nurse can be a differential for the person and his family, because he is usually the element of the health team that provides support for the changes in daily life, alleviating suffering and increasing the capacity of self-care to favor living in this new condition.

According to Orem's theory, self-care is characterized by activities that people perform for their benefit in order to maintain their well-being. The nursing system outlined by the nurse is based on the identification of the care needs, learning capacity, and ability of the patient to perform self-care activities seeking participation in his care plan and independence. Thus, in the preoperative period, the professional seeks to strengthen the preparation of the patients and their families, respecting their individuality, providing information in a slow, gradual and systematic way, so that it obtains greater safety in preparation for surgery and incorporate home self-care after discharge, with the objective of quality of life ${ }^{6}$.

In this context, the following research question emerged: What are the knowledge, perceptions, and needs for self-care in the preoperative period of surgery for the preparation of intestinal stoma? 


\section{OBJECTIVE}

To identify the knowledge, perceptions, and needs of self-care in the preoperative period of surgery for the creation of intestinal stomata.

\section{METHODS}

Qualitative exploratory-descriptive research developed in a surgical hospitalization unit of a teaching hospital in southern Brazil with seven patients in the preoperative period of intestinal surgery. As inclusion criteria were considered: patients over 18 years of age and possible candidates for the intestinal stoma creation. The exclusion criteria were patients who already had a stoma and those who did not agree to participate in the study.

The data were collected through semistructured interviews that addressed questions regarding the person's perceptions of the surgical procedure and their needs for care, life expectancy, and self-care from the preparation of the intestinal stoma. These interviews were 45 minutes long on average. Information was also collected regarding gender, age, religion, education, family income, place of origin, identification of current health status/disease (diagnosis, comorbidities).

During April, May, and June 2016, the patients hospitalized by the coloproctology specialty were investigated in a preoperative period of intestinal surgery with the possibility of performing a stoma, which resulted in ten patients. Thus, contact with each one was made individually, and the objectives of the study were explained, with a formal invitation to participate.

The criterion for data collection closure was the time for research development associated with data saturation, which was achieved with seven patients.

The data were submitted to thematic analysis, organized in three stages: pre-analysis, material exploration, and treatment of the results with inference and interpretation. In the pre-analysis phase, the results of the interviews were prepared with the transcription and codification after thorough reading and organization of the material by similarity. The second phase, material exploration, was obtained through interviews, in order to approximate interpretation and reality, preserving the wealth of information; during this phase, the similarity of the statements was identified to establish the categories. In the phase of treatment and interpretation of the results, the data were separated into thematic categories, which are: preoperative knowledge about intestinal stoma, perceptions, and expectations related to the intestinal stoma and care needs. At this stage, the results were opposed and discussed with relevant literature in the area.

Ethical procedures followed the concepts of the National Health Council Resolution number 466/12. The study was approved by the Committee on Ethics in Research with Human Beings, through report number 931,117 . In order to preserve the confidentiality and anonymity of the participants, the letter $\mathrm{E}$ (interviewee) was used for their designation, in alphanumeric sequence.

\section{RESULTS}

Regarding the sociodemographic data, five men and two women with an average age of 59.2 years participated in the study. As for religion, four were Catholic and three Evangelical. Regarding schooling, three participants had incomplete primary education, and four had 11 years or more of study. Five participants were married, and all were from the great Florianópolis. Most had a monthly income of up to two minimum wages. Four patients were diagnosed with rectal neoplasia, one with ascending colon neoplasia, one with cecum neoplasia, and one with acute, chronic diverticulitis. All of them denied a family history of cancer.

\section{Therapeutic itinerary and associated feelings}

In this category, the participants portrayed the symptoms of the disease, the diagnostic elucidation, and the therapeutic itinerary to presurgical hospitalization. They revealed their feelings about the surgery and the possibility of making an intestinal stoma, as well as their knowledge resulting from previous experience of friends, family, neighbors, or acquaintances. From this experience, the necessity and functioning of intestinal stoma were highlighted.

Regarding the moment of discovery of the diagnosis, most of the participants were surprised, because they 
were healthy people. The search for health care occurred through symptoms such as the presence of enterorrhagia or melena, abdominalgias, and weight loss, as evidenced in their talks.

"I did not feel any pain, I did not worry much, but it started to be the frequency of going to the bathroom, wanting to evacuate, sometimes it was very little, only blood came, and I also started to lose weight" (E1).

"From Christmas onwards, I began to have pains stronger than colic, more and more. In March, I evacuated blood, so I came here to the hospital. The doctor said that if I did not get better, I would have to find a gastroenterologist to do this colonoscopy... I continued with the bleeding, I did it, and the tumor appeared" (E2).

Regarding the tests, all interviewees performed colonoscopy with biopsy for diagnostic confirmation. One participant had chemotherapy and radiotherapy sessions to reduce the tumor before the surgical procedure.

As for the therapeutic itinerary, most of the participants did not follow the current route recommended by the health system in the country, i.e., via primary health care. Many of them sought care in the private network via medical consultation, often without conditions for such resources. From these professionals or through acquaintances, usually health care workers, they were referred to the public health system for complementary exams and surgical referrals.

"My gastroenterologist gave me a referral to CEPON... I did the presurgical exams there... as I have a friend of mine who works here, she looked at the exams and said: I will try to talk to the team here, to see if you do the surgery fast, and that is what happened" (E2).

"I got a consultation at HU... he's already scheduled for my admission to do the tests, and that is where I am here now, waiting to do the surgery" (E7).

The participants indicated the moment of the diagnosis as an impacting event in their lives, referring to feelings of anguish, fear, and concern, but during the hospitalization, they reported being confident and hopeful about the surgical procedure.
"I felt that life is a cycle; it is medicine, technology, I was reassured because at least, a while ago, those who had cancer were condemned to death, and now there is this possibility" (E4).

"My bowel is practically closed. At the time, it was a big shock; I didn't cry much; I didn't know how to react; it seemed that life had stopped for me" (E2).

\section{Knowledge, perceptions, and expectations about intestinal stoma}

This category deals with the participants' perception of the feelings related to the surgical procedure, as well as the expectations of the possibility of making a stoma. Furthermore, it points to the reflections in the lives of these people, highlighting their religiosity and hope as alternatives to remain confident in this process.

When asked about the intestinal stoma, all participants reported total ignorance. When investigating this aspect in greater depth, few reported that a stoma would be an alternative route for intestinal elimination, which is the only aspect they knew about the surgical intervention. They only mentioned that it would be necessary to use a bag placed in the abdomen to collect intestinal elimination.

"I just worry about the bag, the rest I'm comfortable with" (E6).

"I don't have a clue what it's gonna be like. Only what I have in my head is that everything is a normal procedure, because I know several people who have had bowel problems and have had cancer and have a normal life... I do not know how it is done... nor do I know the care" (E1).

"It is somewhere in my abdomen?! Will it be placed somewhere?" (E2).

Despite almost a total lack of clarification and guidance, the participants pointed out the surgical procedure as a possibility of solving the problem or ending the treatment. They reported feelings of apprehension and anxiety about the surgical act; many told their previous surgical experiences as a comparison. In a way, 
they reported tranquility and trust in the team, faith, and religiosity with positive expectations regarding the procedure, embracing spirituality as an alternative for the success of the treatment.

"We get apprehensive, we've never been hospitalized, so we have to try to clear the doubts with the staff, but we'll have to operate anyway" (E3).

"But then it's putting it in God's hand, and the doctor knows what he's doing, and everything is going to be right." (E6).

Another aspect pointed out as a perception was the need to use a colostomy bag as a life change. It is apparent from the statements that all the participants were unaware of the impact that the stoma would have on their lives. They were attached to the idea that its creation would not be necessary and, if it were, it would be for a specific time, performing the surgery for reversal afterward.

"I'm going into surgery, and I'm hoping I won't have to put the little bag in... I'd also like to know if I could reverse... it looks like with four to six months it could reverse" (E4).

“I can't tell you because I don't know what it's gonna look like, if I put it on, I don't even have the idea. After the surgery, I will continue my normal life without that little bag because, with the little bag, I have no idea how it will be" (E5).

The participants had the idea that the stoma was an alternative route to intestinal elimination; they did not accurately report the location, shape, size, or related care. The following statements make clear that, even without fully understanding what it means and what the changes would be, there is apprehension and concern about possible changes in social life and body image.

"I don't know anything, I imagine I'll defecate that way, instead of by the anus it'll be that way. That's what I'm worried about, how this cleanliness will be maintained if I'm going to feel anything if it's going to be forever" (E3).
"I don't know if it causes discomfort if my work routine is going to be the same or if it's going to change, that's what makes me most apprehensive. Also, no, I don't know which part of the bowel" (E7).

\section{Self-care needs of the patient with intestinal stoma}

In this category, the aspects inherent to self-care were addressed, which describe the need for care as relevant in the case of performing an ostomy, their previous knowledge, as well as the fact that the family nucleus collaborates in the strategy of confrontation and support during treatment and care after discharge.

Self-care was related only to personal hygiene, which is the primary concern about the care they would have to perform if they were submitted to the ostomy procedure. Likewise, they did not detail aspects related to this kind of care.

"I don't know, I think that especially what is the care about hygiene, this is a fundamental thing for me to know and how I should put it so it doesn't get misplaced, because then if you don't have good hygiene, you can get an infection, I think this care is very important" (E1).

"I don't know the care, so I'll have to do some research, the thing is to keep it clean. My daily routine, how to change or clean it, take it off and clean, that's the greatest routine I'll have to learn” (E3).

“[...] to know what is right I don't know, I know it's like a little bag, which instead of doing the feces normally, one does in that little bag, but I can't explain what it is” (E6).

One aspect that caught the attention was the fact that male participants reported not wanting to receive guidance on the intestinal stoma in the preoperative period, clinging to the possibility of not needing its making. Female participants, on the other hand, were worried about what was a stoma, how it worked and the importance of clarifying their doubts still in the preoperative period, since this information would bring greater safety and tranquility for the surgical procedure, even knowing that it would only be a possibility. 
"Look, I don't have the slightest idea what it's gonna be like, it's a habit I'm gonna have to get used to, it's all gonna be different. My life to this day is one, but from Tuesday, my life will be another, and I am aware of it" (E2).

"The guy stays in here for a long time and puts a lot of rocks in my head, and it may even pass, be forgotten, and we get a little nervous, so if it's necessary, then we talk to you or someone else who understands, who knows and then explains it better" (E6).

Any of the participants did not mention the issue of health care systems, postsurgery care processes, where they could have access to equipment, adjuvants, and other available support networks.

After the questioning about self-care with the intestinal stoma was deepened, the patients reported a quick search on the internet, and of information with friends or relatives who had it, as well as the coexistence with other patients in the same room about the stoma.

From the perspective of the support network, the participants mentioned the family as a support for dealing with the disease, and the men named their wives as the main caregivers if they needed the procedure.

"Look, learning is not too much, I could even try to learn to make it a little easier, but I'm sure she (wife) will do, at least in the beginning she will undoubtedly do" (E4).

"I wanted to learn a little, of course, and, my wife, I wanted her to know how she does it, how she doesn't do it, so that we can always do it right to avoid mistakes" (E6).

\section{DISCUSSION}

Bypass surgery of intestinal transit causes several changes in people, provoking suffering, fear, pain and insecurity, even if it means the possibility of improvement of the signs and symptoms that originated it and often the cure of a certain disease 6 . The surgery to make an intestinal stoma is a remarkable moment for any person and is considered a life expectancy and, therefore, these people try to adapt to their new condition, which is seen positively, as an alternative to solve their health problem ${ }^{7}$. The participants, despite reporting experiencing these feelings, somehow denied the reality, in the hope that there would be no need to make the intestinal stoma.

The nurse, by providing information to patients in surgical condition, gives the possibility of understanding their current health condition, providing them with alternatives for their active participation in health care, motivating changes and alleviating feelings of fear, anxiety, anguish and blockages for action, caused by ignorance ${ }^{8}$. The importance of patients receiving guidance on the perioperative period is highlighted, which provides greater safety in the face of their health situation, until then unknown, generating a better understanding of what they experience, learning to take care of themselves. However, one aspect observed in this research was that men did not accept the guidelines for this period or the postoperative period. The women interviewed mentioned the importance and willingness to be educated in advance. This fact is possibly associated with a characteristic of male identity related to its socialization process, in which, most of the time, the devaluation of self-care and incipient concern with health prevail, delegating to the female figure this responsibility in the most varied aspects.

The person facing surgery to make an intestinal stoma may suffer physiological, psycho-spiritual and psychosocial changes. This whole process can trigger feelings of depression, loneliness, feelings of mourning, with a consequent loss of self-esteem, alteration of self-image, insecurity and fear of the unknown. These aspects cause changes in social life; for fear of accidents with the bag, such as odor, elimination of gases or rupture, they change their clothing to hide the collecting device. Besides, fear and embarrassment occur in the work environment, demonstrate fear of not being able to perform some activities because of having a stoma, which can lead to the absence of work activities and changes in family dynamics ${ }^{1,4,9}$. Feelings of anguish and concern similar to those mentioned in the literature were evidenced in all the participants' statements, revealing their weaknesses in the face of this possibility of modification.

Studies show that the construction of a definite concept or image of surgery and the preparation for the experience of making the stoma and its changes still in the preoperative may facilitate the learning process of self-care. It was observed that the teaching for this experience, its care and its transformations before the surgical procedure soften the transition process and the impact of this episode, facilitating the confrontation and development of strategies for self-care, helping in the acquisition of skills by the previous knowledge 
of what was expected for them after the surgery. The lack of information in the preoperative period may lead to physical and psychological changes, making the postoperative period more difficult ${ }^{7,10,11}$ which was corroborated in this study, because most patients reported that they did not have very elaborate information on the procedure for making the stoma and would prefer to have it only in the postoperative period, if necessary.

In this sense, two studies point to the precariousness of information in the preoperative period, the lack of articulated care in all phases of the surgical process and the information performed punctually, centralized only in surgery, without the involvement of the whole context of change that a stomia causes in the life of the individual, as hinders the acceptance of the stoma, self-care and the adaptation of new life habits, thus questioning how nursing interventions are being performed in this period that covers so many expectations and anxiety for the patient. For this reason, it is important to emphasize the importance of guidance to the patient and relatives on the making of the stoma, its possible difficulties and needs for care before surgery, continuously performed, with exchange of knowledge and experience, respecting the demand of the patient, and the nurse acting as the facilitator in the process of acceptance, thus contributing to a positive outcome in care $^{6,12}$.

In this interactive space, the nurse can and must use care strategies to identify the consequences and specific modifications suffered by the person. This will directly influence the teaching of self-care, the indication of the type of collecting equipment and adjuvants, considering the type of stoma, the individual needs and the prevention of complications in the stoma and peristomal $\operatorname{skin}^{13}$. Also, in the preoperative period, the nurse must perform the previous demarcation where the stoma will be located, because many related complications can be avoided with this procedure and with the use of appropriate surgical technique ${ }^{14}$.

The development of new activities in daily life overloads the family environment, especially when the mother or wife is the basis of care for all members. Therefore, faced with the process of illness, the woman caregiver needs to reorganize the functioning of the family and carries the weight of thess activities $^{6}$. This statement strengthens the finding with the male interviewees who highlighted the female figure as the central pillar for sharing his care about the stoma. The women, on the other hand, mentioned the family nucleus only as psychological support assuming the possibility of this new condition and their self-care individually, if necessary.

In addition to family support, respondents mentioned searching for information on the internet, previous experiences, and contact with roommates as strategies to understand what a stoma is and to describe their basic care when asked. The contact with people in a similar situation or who have already been through the same experiences helps positively in the adherence to treatment and acceptance of the new life condition, making the individual feel part of society ${ }^{7}$. Regarding the internet, there are controversies, as much information found is not reliable and/or scientific, which may trigger inadequate care by the patients and their relatives.

Faith or the search for divine help make the human being seek resources to face daily challenges, which is a vital instrument for pain relief. Religious beliefs influence the way human beings face their problems and collaborate for better acceptance and confrontation of difficulties, facilitating the reflection about living and making the resignification of life possible, confirming the statements of those interviewees who brought faith and religiosity as a strategy to confront ${ }^{10,12}$.

The importance of self-care, whose objective is the execution of activities performed by individuals for their benefit to maintain life, health, and well-being by proposing the encouragement of patients to take care of themselves with autonomy, actively participating in the care process ${ }^{15}$. The development of skills for self-care is directly influenced by the culture, beliefs, lifestyles, and physical and emotional aspects of each individual and it is essential to have adequate nursing care in a hospital environment along with the person with stoma, in order to reduce anxiety, increase safety and the development of skills for handling the stoma, making the patient able to perform his/her selfcare ${ }^{4,11}$.

The nursing system theory proposed by Orem describes that professionals plan care concerning the patient's need for self-care and the ability to perform it. Thus, the nurse should apply the teaching method in order to promote selfcare, facilitating reasoning and understanding, establishing actions that help in the patient's independence ${ }^{6}$.

Family support is a fundamental part of the process of accepting the stoma, encourages the individuals to develop positive attitudes, strengthen their autonomy, improve their self-esteem, and ease the stoma adaptive and rehabilitative process $^{4,7}$. In this study, all interviewees pointed out the family as the basis for support and strength for better 
facing the illness process, corroborating with the authors mentioned above.

In this premise, the knowledge of professionals and subjects should be shared in the process of caring, involving, and valuing the social and family context of the subject, enabling him to overcome the challenges. Contemplating also the Orem's theory, the importance of the involvement of the patients and their families in self-care is highlighted, making them responsible for the effective development of their care and thus contributing to a better quality of life, health and well-being ${ }^{2}$.

Hygiene care of the stoma and peristomal skin, their observation and the care with the collector system are essential aspects of the care of the person with stoma ${ }^{16}$. This aspect reinforces the interviewees' statements, who, even without knowing how to mention much care with the stoma, reported concern about the way hygiene is performed, presenting it as the main care.

The interviewees did not mention concerns about the therapeutic itinerary and the flow of care after hospital discharge, keeping the focus only on the surgical procedure and the possibility of not needing the ostomy procedure. Self-help groups, programs of care for the person with a stoma and reference spaces in specialized care are essential in the process of acceptance and minimization of suffering, through the exchange of knowledge, experiences among people with a stoma, provision of scholarships and support from professionals can facilitate teaching and learn about care and self-esteem ${ }^{17}$.

Ministry of Health Ordinance 400 from 16 November 2009 establishes responsibilities such as the rehabilitation of people with a stoma, emphasizes self-care, the prevention of complications and the supply of collecting equipment and adjuvants for protection and safety ${ }^{18}$. All these instruments are considered facilitators, related to the community aiming at the transition, preventing the individual from having a problematic itinerary in search of care ${ }^{3,7}$ in order to reflect the support and education system, in which the person performs and regulates his/her self-care activities. The nurse has an important role in supporting the achievement of self-care ${ }^{15}$.

\section{FINAL CONSIDERATIONS}

This study allowed us to know the conditions experienced by patients in the preoperative period of surgery, generating intestinal stoma, evidencing this phase by the perceptions of feelings of anguish, fears, concerns and uncertainties in the face of the diagnosis impacts as well as the whole process of illness. Also, the sudden news of the possibility of making a stoma, often unknown to most people, brings to light different feelings and behaviors. The denial of this possibility, confidence in the surgical procedure, family support, and religiosity were factors identified in the process of confrontation and acceptance.

The limitations of this study are the small number of interviewees as well as the reflection of reality limited to a university hospital, which may be different in other realities. Even so, these data serve as an alert for the importance of nursing care and for the nurse's performance, which should be contemplated in the pre-, trans- and postoperative periods.

The contribution of this study lies in the importance of the therapeutic itinerary of these patients until the indication of the need to make an intestinal stoma, in order to investigate the actions of prevention, health promotion and early diagnosis employed by the family health strategy teams, especially those developed by nurses. Also, the route after discharge from the hospital, as well as the investigation of the health system and social support used, in order to know how the line of care is configured for this patient in the public health system.

Nursing care technologies, such as guidance manuals are important tools for these patients. They must be by the needs indicated by this clientele, including the concept and types of stomata, types of equipment available and used for the care of people with intestinal stoma, hygiene and comfort care, type of clothing, practice of physical activities, social and family life, food, sexuality, rights, support network and useful contacts (associations, governmental and nongovernmental entities).

\section{AUTHORS' CONTRIBUTION}

Conceptualization, Morais GX and Girondi JBR; Methodology, Morais GX and Girondi JBR; Investigation, Morais GX, Girondi JBR and Vieira AS; Writing - Original Draft, Morais GX, Girondi JBR, Amante LN and Sebold LF; Writing - Review and Editing, Morais GX, Girondi JBR, Amante LN, Sebold LF and Souza FR; Supervision, Girondi JBR. 


\section{REFERENCES}

1. Silva ES, Castro DS, Romero WG, Garcia TR, Primo CC. Protocolo de enfermagem para as alterações psicossociais e espirituais da pessoa com colostomia. Cogitare Enferm. 2015;20(3):466-74. https://doi.org/10.5380/ce.v20i3.40664

2. Mota MS, Gomes GC, Silva CD, Gomes VLO, Pelzer MT, Barros EJL. Autocuidado: uma estratégia para a qualidade de vida da pessoa com estomia. Investig Enferm Imagen Desarr. 2016;18(1):63-78. https://doi.org/10.11144/Javeriana.ie18-1.aeqv

3. Silva CRDT, Andrade EMLR, Luz MHBA, Andrade JX, da Silva GRF. Qualidade de vida de pessoas com estomias intestinais de eliminação. Acta Paul Enferm. 2017;30(2):144-51. https:// doi.org/10.1590/1982-0194201700023

4. Costa AT, Santana PPC, Teixeira PA, Santo FHE, Flach DMAM, Andrade M. Evidências científicas de enfermagem sobre idosos estomizados. Rev Enferm Atual. 2016;79(17):41-9.

5. Maia EMB, Assis GM. Percepção dos pais de crianças com estomia intestinal a respeito das orientações de enfermagem. ESTIMA, Braz J Enterostomal Ther. 2019;17(e0819):1-8. https://doi.org/10.30886/estima.v17.663_PT

6. Ribeiro WA, Andrade M. O autocuidado em pacientes estomizados a luz de Dorothea Orem: da reflexão ao itinerário terapêutico. Revista Pró-UniverSUS. 2018;9(2):109-12.

7. Sena RMC, Nascimento EGC, Sousa WPS, Oliveira MAM, Maia EMC. Aspectos emocionais do indivíduo no enfrentamento da condição de estomizado. ESTIMA, Braz J Enterostomal Ther. 2017;15(1):43-9. https://doi.org/10.5327/Z18063144201700010007

8. Mota MS, Gomes GC, Petuco VM, Heck RM, Barros EJL, Gomes VLO. Facilitadores do processo de transição para o autocuidado da pessoa com estoma: subsídios para a enfermagem. Rev Esc Enferm USP. 2015;49(1):82-8. https:// doi.org/10.1590/S0080-623420150000100011

9. Carvalho SORM, Budó MLD, Silva MM, Alberti GF, Simon BS. "Com um pouco de cuidado a gente vai em frente": vivências de pessoas com estomia. Texto Contexto Enferm. 2015;24(1):279-87. https://doi.org/10.1590/010407072015003710013

10. Rocha DM, Gonçalves LCS, Costa JGM, Silva Junior RF. Conhecendo melhor indivíduo com ostomia ou ostomizado: com relação à imagem corporal e o psicológico. UNINGÁ Rev. 2019;56(S2):94-9.

11. Freire DA, Angelim RCM, Souza NR, Brandão BMGM, Torres KMS, Serrano SQ. Autoimagem e autocuidado na vivencia de pacientes estomizados: o olhar da Enfermagem. Rev Min Enferm. 2017;21(e1019):1-7. https://doi.org/10.5935/14152762.20170029

12. Silva NM, Santos MA, Rosado SR, Galvão CM, Sonobe HM. Aspectos psicológicos de pacientes estomizados intestinais: revisão integrativa. Rev Latino-Am Enfermagem. 2017;25:111. https://doi.org/10.1590/1518-8345.2231.2950

13. Person B, Ifargan R, Lachter J, Duek SD, Kluger Y, Assalia A. The impact of preoperative stoma site marking on the incidence of complications, quality of life, and patient's independence. Dis Colon Rectum. 2012;55(7):783-7. https:// doi.org/10.1097/DCR.0b013e31825763f0

14. Moraes JT, Silva AE, Silva MDM, Guimarães RO, Ferraz GB. A Percepção de Cirurgiões sobre o Cuidado em Estomias. J Health Sci. 2017;19(1):14-8. https://doi.org/10.17921/24478938.2017v19n1p14-18

15. Ribeiro WA, Andrade M, Couto CS, Souza DMS, Morais MC, Santos JAM. As contribuições do enfermeiro no autocuidado ao paciente estomizado: uma revisão integrativa. Revista Pró-UniverSUS. 2019;10(1):72-5. https://doi.org/10.21727/ rpu.v10i1.1683

16. Nascimento DC, Chagas CC, Souza NVDO, Marques GS, Rodrigues FR, Cunha CV, et al. Experiência Cotidiana: a visão da pessoa com estomia intestinal. ESTIMA, Braz J Enterostomal Ther. 2016;14(4):183-92. https://doi. org/10.5327/Z1806-3144201600040005

17. Sousa ARA, Menezes LCG, Miranda SM, Cavalcante TB. Estratégias educativas para pessoas com estomia intestinal: revisão integrativa. Rev Enferm Atual. 2017;81(19):81-8.

18. Portaria $n^{\circ}$ 400, de 16 de novembro de 2009 (BR). Estabelece diretrizes para a organização dos Serviços de Atenção a Pessoas Estomizadas no país. Diário Oficial da União, Brasília (DF). 17 de novembro de 2009 [citado em 8 de julho de 2019]. Disponível em: http://bvsms.saude.gov.br/ bvs/saudelegis/sas/2009/prt0400_16_11_2009.html 